\title{
Burnout Syndrome in Public Servants: Prevalence and association with Occupational Stressors
}

\author{
Mary Sandra Carlotto ${ }^{1}$ \\ Sheila Gonçalves Câmara ${ }^{2}$ \\ ${ }^{1}$ Universidade do Vale do Rio dos Sinos, São Leopoldo, RS \\ ${ }^{2}$ Universidade Federal de Ciências da Saúde de Porto Alegre, Porto Alegre, RS
}

\begin{abstract}
The objectives of this study were to identify the prevalence of Burnout Syndrome (BS) and the predictive power of occupational stressors for its dimensions - Enthusiasm toward the job (inverse), Psychological Exhaustion, Indolence and Guilt. This study assessed a random sample of 538 public servants from a State Court of Justice (RS/Brazil) who answered the Spanish Burnout Inventory, a sociodemographic questionnaire, a work-related questionnaire and and occupational stressors questionnaire. The prevalence identified was $6.5 \%$ for Profile 1 BS (Enthusiasm toward the job - inverse, Psychological Exhaustion, Indolence) and $4.4 \%$ for Profile 2 BS (Enthusiasm toward the job - inverse, Psychological Exhaustion, Indolence, Guilt). Stressors that predicted Burnout Syndrome were work content, work organization, type of public served, social environment of work, physical conditions of the workplace, work hours, workload, relationship with heads, and relationship with colleagues. Results suggest a need for intervention in occupational stressors present in work organization.

Keywords: burnout syndrome; occupational stress; public servants; worker's health
\end{abstract}

Síndrome de Burnout em Funcionários Públicos: Prevalência e associação a Estressores Ocupacionais

\section{Resumo}

Os objetivos do estudo foram identificar a prevalência da Síndrome de Burnout (SB) e o poder preditivo dos estressores ocupacionais para as suas dimensões - Ilusão pelo trabalho (inversa), Desgaste Psíquico, Indolência e Culpa. Este estudo avaliou uma amostra aleatória de 538 servidores públicos de um tribunal de justiça (RS/Brasil) que responderam ao Spanish Burnout Inventory, um questionário sociodemográfico, um questionário de dados laborais e um questionário de estressores ocupacionais. A prevalência identificada foi de 6,5 \% para SB-Perfil 1 (Ilusão pelo trabalho - inversa, Desgaste Psíquico, Indolência) e de 4,35\% para SB-Perfil 2 (Ilusão pelo trabalho - inversa, Desgaste Psíquico, Indolência, Culpa). Os estressores que predisseram a Síndrome de Burnout foram o conteúdo do trabalho, a organização do trabalho, o tipo do público atendido, ambiente social do trabalho, as condições físicas do local de trabalho, o horário de trabalho, a carga horária, a relação com a chefia, e a relação com os colegas. Os resultados sugerem a necessidade de intervenção nos estressores ocupacionais presentes na organização do trabalho.

Palavras-chave: síndrome de burnout; estresse ocupacional; servidores públicos; saúde do trabalhador

\section{Síndrome de Burnout en Funcionarios Públicos: Prevalencia y asociación a Estresores Ocupacionales}

\begin{abstract}
Resumen
El objetivo del estudio fue identificar la prevalencia del síndrome de Burnout (SB) y el poder predictivo de los estresores ocupacionales para sus dimensiones - Ilusión por el trabajo (inversa), Desgaste Psíquico, Indolencia y Culpa. Ese estudio evaluó una muestra aleatoria de 538 funcionarios públicos de un tribunal de justicia (RS / Brasil) que respondieron el Spanish Burnout Inventory, un cuestionario sociodemográfico, un cuestionario de datos laborales y un cuestionario de estresores ocupacionales. La prevalencia identificada fue de 6,5\% para SB Perfil 1 (Ilusión por el trabajo- inversa, Desgaste Psíquico, Indolencia) y de 4,35\% para SB Perfil 2 (Ilusión por el trabajo-inversa, Desgaste Psíquico, Indolencia, Culpa). Los estresores que predijeron el síndrome de Burnout fueron: contenido de trabajo, organización de trabajo, tipo de público atendido, ambiente social de trabajo, condiciones físicas de local de trabajo, horario de trabajo, carga horaria, relación con los superiores y relación con los compañeros. Los resultados sugieren la necesidad de intervención en los estresores ocupacionales presentes en la organización del trabajo.

Palabras clave: Síndrome de Burnout; estrés ocupacional; funcionarios públicos; salud del trabajador
\end{abstract}

The matter of public management aimed at results becomes central as of the 1980s and 1990s due to the expansion of guarantee to fundamental rights and the extension of the population's access to the possibility of contesting the constitutionality of laws, both set forth by 1988 Federal Constitution. Such a possibility intensified the search for Judiciary Power services in Brazil, resulting in the need for significant changes in the administrative nature of this institution (Nogueira, Oliveira, Vasconcelos, \& Oliveira 2012). This important transformation in the management model of organizations led to new work dynamics, which presupposes the 
incorporation of new technologies and new management practices. This has caused pronounced changes in the work environment of public organizations with the basic purpose of achieving a more productive performance (Balassiano, Tavares, \& Pimenta, 2011; Louro, Santos, \& Zanquetto Filho, 2017).

Managerial public administration or new public management is a post-bureaucratic normative model for the structuration and management of public administration based on efficiency, efficacy and competitiveness values (Secchi, 2009), whose objective is the achievement of a better performance and systematization of organizational activities (Lima \& Silva, 2015). The adoption of this model has made public services comply with parameters of private companies in order to become efficient (Aquino, 2010). The managerial focus was then placed on citizens, with the aim of providing public services with greater quality so as to meet the demands of their users (Coutinho, 2000, Reis, 2016). In addition to attend to efficiency and effectiveness, public managers nowadays are expected to create public value and to involve citizens in decision-making processes (Suárez \& Esparza, 2015).

This new work configuration has become complex and multifaceted with increment of occupational stressors that have made workers more vulnerable to occupational diseases (Chopra, 2009). Psychosocial factors are conditions present in a work situation and directly related to work organization, work content and work environment, which can be turned into stressors and affect work development and a worker's health (Gil-Monte, 2014).

Occupational stressors, when persistent, may cause the Burnout Syndrome (BS), regarded as the result of chronic stress, typical of work routine, especially when there is excessive pressure, conflicts, little emotional reward, recognition and success (Harrison, 1999). According to Gil-Monte (2008), from a psychosocial perspective, Burnout is not a psychological stress but rather a response face sources of chronic occupational stress.

The BS model proposed by Gil-Monte (2005) consists of four dimensions: 1) enthusiasm toward the job: defined as an individual's desire to achieve his work goals, with work being understood as a source of personal pleasure. The subject perceives his job as attractive, and achieving professional goals becomes a source of personal accomplishment; 2) psychological exhaustion: it is characterized by the appearance of emotional and physical fatigue due to having to deal daily while working with people who present or cause problems; 3) indolence: presence of negative attitudes of indifference, insensibility and detachment in relation to clients, colleagues and the organization.; 4) guilt: defined as a social emotion linked to interpersonal relations that is caused by negative behavior and attitudes developed at work, especially towards people with which workers need to establish labor relations. The worker believes he is violating some sort of ethical code or a norm derived from the prescription of his professional role.

For assessment purposes, the theoretical model defends the existence of two Burnout profiles: Profile 1 , characterized by a set of feelings and attitudes about work-related stress, which originate a moderate form of malaise, without, however, making individuals unfit to perform their jobs, even though they are capable of doing it better. It consists of a cognitive deterioration (lack of enthusiasm toward the job) and affective deterioration (psychological exhaustion) that emerge as a first response to sources of chronic stress, developing afterwards negative behaviors (indolence) towards people who they need to serve while working. Profile 2 shows the same dimensions in addition to the guilt dimension. This profile is characterized by a greater damage to individuals, with the latter possibly showing serious problems in the execution of their jobs, followed by longer periods away from work and psychiatric comorbidities.

In the public administration field, there is still lack of researches about occupational stress in Brazil (Balassiano, Tavares, \& Pimenta, 2011) and Burnout (Carlotto \& Câmara, 2008; Malmann, Palazzo \& Carlotto, 2009). Although Brazilian laws contemplate, since 1999 , BS as a mental and behavioral disorder related to work, belonging to CID-10 Group V, through Decree No 3048/99, and its characterization is described in the manual of procedures for health services (Brazil's Ministry of Health, 2001), knowledge about the syndrome, as to both workers and medical expertise, remains limited (Batista, Carlotto, Coutinho \& Augusto, 2011).

Study conducted by Fonseca and Carlotto (2011) with judiciary servants from the state of Rio Grande do Sul, based on the year of 2009, identified that $16.5 \%$ missed work due to sick leaves. Among all leaves, 219 (16.2\%) resulted from Mental and Behavioral Disorders (F00-F99 in CID-10), which may often be related to work (Batista, Carlotto, Coutinho, \& Augusto, 2011; Falavigna \& Carlotto, 2013). Another investigation, with public servants from Tocantins' Executive Power, 
conducted by Oliveira, Baldaçara and Maia (2015), found that $51.9 \%$ of leaves occurred due to Mental and Behavioral Disorders. The authors attribute the results to several stressful factors that made up the routine of public servants' jobs, such as intense demand from services, precarization of physical structures, in addition to public management and government political changes that change work routines and processes, among others.

Occupational stressors and pathologies related to them have been identified as one of the biggest current challenges to health and occupational safety Jain, Saeed, Arnaout \& Kortum, 2012; Laranjeira, 2009, World Health Organization, 2017). Thus, by the exposed, this cross-sectional epidemiological study sought to identify BS prevalence and the predictive power of occupational stressors for their dimensions in workers from a judiciary institution in Rio Grande do Sul, Brazil.

\section{Method}

\section{Participants}

The study population was made up by 8.185 servants belonging to the functional staff of the Judiciary Power, who performed their jobs in Districts distributed into 164 cities in the state of Rio Grande do Sul. The sample size was calculated for a 95\% confidence internal, $5 \%$ error margin, $50 \%$ BS prevalence, value estimated when there is no information about the proportion of interest (Agranonik \& Hirakata, 2011), and $10 \%$ for eventual losses. The calculation resulted in a sample of 679 workers that were randomly drawn, with the obtainment of a response rate of $80.7 \%$, that is, 548 servants. Inclusion criterion was being professionally active for more than one year.

The majority of the sample was composed of females $(65.9 \%)$, with stable marital relationship $(58.60 \%)$ and with children $(51.80 \%)$. The average age was 43 years old $(S D=8.40)$. Regarding education, $80.10 \%$ had completed higher education and specialization. They had been working, on average, 13 years and 6 months $(\mathrm{SD}=8.36)$ at the institution and had 9 years $(S D=7.20)$ of experience in their current role.

\section{Instruments}

Data were collected through the following instruments: (1) sociodemographic questionnaire (sex, age, education, marital status, children), (2) work-related questionnaire (time working at the institution, time in the role) and (3) occupational stressors questionnaire (type of job performed; work hours; schedule; workload; diversity of work; complexity of work; public served; relationship with colleagues; relationship with heads; physical conditions of work; organization of work). The items were assessed through a 5-point Likert-type scale, ranging from 0 (zero) "Not stressful at all to 4 (four) "Very stressful", (4) Spanish Burnout Inventory - SBI (Gil-Monte, 2005; Carlotto, Gil-Monte, \& Figueiredo-Ferraz, 2015). The latter consists of 20 items distributed into four subscales called: enthusiasm toward the job, assessed inversely, low scores in this dimension mean high Burnout levels (5 items, $\alpha=0.86$, e.g.: I see my job as a source of personal accomplishment), psychological exhaustion (4 items, $\alpha=$ 0.85, e.g.: I feel emotionally exhausted), indolence ( 6 items, $\alpha=0.72$, e.g.: I don't like taking care of some people), and guilt (5 items, $\alpha=0.81$, e.g.: I regret some of my behaviors at work). The items are assessed with a 5-point Likerttype scale (0 "Never" to 4 "Every day"). Cronbach's $\alpha$ in this sample was 0.93 for enthusiasm toward the job, 0.85 for de psychological exhaustion, 0.70 for indolence and 0.83 for guilty.

\section{Procedures}

Data were collected by means of an online assessment available through the organization's intranet. Drawn servants received individual codes and passwords to access the system in the period of a week.

The database was analyzed on PASW statistical package, version 17 (SPSS/PASW, Inc., Chicago, IL). First, descriptive analyses of exploratory nature were carried out in order to assess, on the database, the distribution of the items, missing cases and identification of extremes. To calculate prevalence, cutout points present in the instrument's manual were used (Gil-Monte, 2011). The calculation of Burnout Profile 1 considered the mean of all 15 items of enthusiasm toward the job (inverted), psychological exhaustion and indolence subscales, and, for Profile 2, the guilt dimension was added (Gil-Monte, 2005, 2011; Gil-Monte, Carlotto, \& Câmara, 2010).

The analysis took as dependent variables BS dimensions (enthusiasm toward the job, psychological exhaustion, indolence and guilt) and occupational stressors as independent variables. The selection of predicting variables adopted a $p<.05$ level of significance. In the regression analysis, the effect power was obtained by regression coefficients standardized and calculated for each final model (Field, 2009). 
The project was approved by the Ethic and Research Committee of [institution name omitted for review]. As for access to the instrument, the participants were informed about the voluntary, anonymous and confidential character of data.

\section{Results}

Results displayed in Table 1 evidence that 31.0\% of participants show low level of enthusiasm toward the job, $31.5 \%$ high level of psychological exhaustion, $17.3 \%$ high level of indolence, and $9.7 \%$ of guilt. Among the participants, 6.5\% fit into Profile 1 and $4.4 \%$ into Profile 2.

Table 2 shows results of the linear regression analysis, which considered Burnout dimensions as dependent variables, and occupational stressors as predicting variables. The prediction analysis of the enthusiasm toward the job dimension evidenced an explanatory model composed of 4 variables that, altogether, explained $20.1 \%$ of the variance of this dimension, with social environment of work the variable with the greatest explanatory power $(13.9 \%)$. The set of variables reveals that, as the perception that the social environment of work, the work content, the work schedule and the relationship with heads are stressful increase, lack of enthusiasm about work increases as well.

The variation in the psychological exhaustion dimension is explained by 5 variables that jointly explain $47.9 \%$ of the variance. The result indicates that the greater the perception of stress related to work content, to the social environment of work, to work hours, to physical conditions of work and to relationship with heads, the greater the feeling of psychological exhaustion. It is worth highlighting that the variable with the highest explanatory power is work content (32.4\%).
Indolence was explained in $35.3 \%$ by perception of the social environment of work, type of public, relationship with colleagues and heads as stressors, with social environment of work variable being that with the highest explanatory power $(21.9 \%)$. Perceiving these work situations as stressful strengthens the behavior of indifference and detachment in relations. Finally, the regression analysis for the dependent variable guilt revealed as predicting variables the relationship with colleagues and type of public stressors, with $5.6 \%$ of the variance, and with the relationship with colleagues variable accounting for $4.6 \%$ of the explanation of the dimension. This result indicates that with an increase in the perception that the relationship with colleagues and the type of public served are stressful, there is an increase in the feeling of guilt due to the perception that the servant does not meet the social expectations of his role.

Results reveal an effect power between low $\left(\mathrm{R}^{2}=0.048\right)$ and high $\left(\mathrm{R}^{2}=0.484\right)$ in accordance with parameters recommended by Field (2009). This thus indicates that, with the exception of explanatory variables in the Guilt dimension, identified relations will possibly be present in other samples of servants as well.

\section{Discussion}

The present study sought to identify the prevalence of Burnout Syndrome and occupational stressors predicting its dimensions in a sample of judiciary servants. The analysis of Burnout profiles reveals that 35 participants (6.5\%) belong to Profile 1, and 23 (4.4\%) to Profile 2, considered as the most serious one. Both results are inferior to those identified in school teachers $(n=714)$ conducted by Gil-Monte, Carlotto and Câmara (2011), which identified $12.0 \%$ classified into

Table 1.

Prevalence of Burnout Syndrome dimensions and profiles in public servants

\begin{tabular}{lcccc}
\hline Dimensions & \multicolumn{2}{c}{$\mathrm{M}<90$} & \multicolumn{3}{c}{$\mathrm{M} \geq 90$} & $\%$ \\
\hline Enthusiasm toward the job & $\mathrm{N}$ & $\%$ & 371 & 69.0 \\
Psychological exhaustion & 167 & 31.0 & 169 & 31.5 \\
Indolence & 369 & 68.5 & 93 & 17.3 \\
Guilt & 455 & 82.7 & 52 & 9.7 \\
Profile 1 & 486 & 90.3 & 35 & 6.5 \\
Profile 2 & 503 & 93.5 & 23 & 4.4 \\
\hline
\end{tabular}


Table 2.

Model of the multiple linear regression analysis of Burnout (DV) and occupational stressors (IV) in public servants

\begin{tabular}{|c|c|c|c|c|c|c|c|}
\hline & $\mathrm{R}^{2}$ & $\underset{\text { Adjusted }}{\mathrm{R}}$ & $\begin{array}{c}\mathrm{R} \\
\text { change }\end{array}$ & B & SE & $\beta$ & $t$ \\
\hline \multicolumn{8}{|c|}{ Enthusiasm toward the job (inverse) } \\
\hline Social environment of work & .139 & .138 & .139 & .190 & .051 & 0.189 & $3.729 * *$ \\
\hline Work content & .182 & .179 & .043 & .223 & .053 & 0.197 & $4.213^{* *}$ \\
\hline Work schedule & .198 & .193 & .016 & .160 & .048 & 0.140 & $3.297 * *$ \\
\hline Relationship with heads & .208 & .201 & .010 & .117 & .047 & 0.113 & $2.466^{*}$ \\
\hline Model F & \multicolumn{7}{|c|}{$32.517 * *$} \\
\hline \multicolumn{8}{|l|}{ Psychological exhaustion } \\
\hline Work content & 326 & .324 & .326 & .326 & .340 & .041 & $0.318^{* *}$ \\
\hline Social environment of work & .400 & .398 & .075 & .075 & .164 & .040 & $0.173^{* *}$ \\
\hline Work hours & .452 & .449 & .052 & .052 & .259 & .040 & $0.225^{* *}$ \\
\hline Physical conditions of work & .478 & .474 & .026 & .026 & .167 & .035 & $0.182^{* *}$ \\
\hline Relationship with heads & .484 & .479 & .017 & .066 & .090 & .036 & $0.092^{*}$ \\
\hline Model F & \multicolumn{7}{|c|}{$42.857 * *$} \\
\hline \multicolumn{8}{|l|}{ Indolence } \\
\hline Social environment of work & .221 & .219 & .221 & .122 & .033 & .176 & $3.720 * *$ \\
\hline Type of public & .294 & .291 & .072 & .200 & .029 & .271 & $6.919 * *$ \\
\hline Relationship with colleagues & .343 & .339 & .049 & .195 & .039 & .224 & $4.964 * *$ \\
\hline Relationship with heads & .358 & .353 & .015 & .104 & .031 & .146 & $3.414^{* *}$ \\
\hline Model F & \multicolumn{7}{|c|}{$67.869 * *$} \\
\hline \multicolumn{8}{|l|}{ Guilt } \\
\hline Relationship with colleagues & .048 & .046 & .048 & .149 & .038 & .181 & $3.917 * *$ \\
\hline Type of public & .060 & .056 & .013 & .084 & .033 & .118 & $2.552^{*}$ \\
\hline Model F & \multicolumn{7}{|c|}{$15.687 * *$} \\
\hline
\end{tabular}

Note: ${ }^{*} \mathrm{p}<0.05,{ }^{* *} \mathrm{p}<0.01$

Profile 1 and 5.6\% into Profile 2, and in a study with a sample of 518 psychologists, whose prevalence was $7.5 \%$ in Profile 1 and $9.8 \%$ in Profile 2 (Rodriguez \& Carlotto, 2014).

This result, in what concerns profile 1 , may be related to the characteristics of a public servant's job, whose activity is based on a formal and impersonal model expressed as documented norms, complying with a legal rite that precisely defines roles, systematicity of routines and work processes (Mota \& Pereira, 2004). It is important to highlight that professionals that fit into this profile can stay many years at the organization without developing relevant individual problems linked to stress, even though, with their attitudes and Psico-USF, Bragança Paulista, v. 24, n. 3, p. 425-435, jul./set. 2019 behaviors, they present poorer performance and quality at work (Gil-Monte, 2005).

In Profile 2, considered the most serious one, it is possible that the public servants are more attentive to the new management model, whose focus is more aimed at meeting the users' demands (Cavalcante, 2017; Coutinho, 2000). A study conducted by Silva and Barbosa (2016) with Judiciary Power servants identified that part of the interviewees reveals the existence of new demands, administrative and social, which impose a new attitude and adaptation from workers. In this sense, it is possible to think that workers, feeling that they are not able to handle this demand and social pressure, feel guilty and, as a consequence, show more serious health problems. According to Gil-Monte (2012), workers 
that fit into this profile present a higher frequency of medical consultations, health problems, generally of psychosomatic nature, and long-term leaves, which may lead to incapacity for work.

The 58 cases identified in the present study could be classified as BS-potential, when considering Brazilian laws and the theoretical model used. The obtained result is worth attention, bearing in mind that workers in both profiles are fully active, probably worsening their health condition and with losses to the quality of their job. Over time, the work-related pathology, due to the continuous process of daily adaptation, leads to some other pathology that is not related to work (Carlotto, 2010), with depression being one of the most prevalent associated comorbidities (Gil-Monte, 2012; Jardim, 2011). It is even more worrisome the finding that 23 workers fit into Profile 2 because they may be already presenting symptoms that will cause greater losses and long-term leaves.

It is important to highlight that, in all cases, there is a need to conduct clinical interviews and other methods for psychological assessment in order to confirm the diagnosis. In addition, it is important to discard other problems that may be influencing the assessed symptoms, as well as to enable the analysis of Burnout consequences and the degree of incapacity to work (Gil-Monte, 2008).

As for the prevalence of dimensions and related stressors, $31.0 \%$ of the participants show feelings of lack of enthusiasm toward the job, a figure higher than the $10.4 \%$ obtained in a study conducted with Brazilian teachers (Gil-Monte, Carlotto \& Câmara, 2011). This results, related to functional motivation, may be indicating a conflict between professional expectations and the job actually performed. A possibility that can explain the result could be related to the fact that most of the sample professionals have higher education $(80.10 \%)$, and the servants, not necessarily, join the public service with posts that are compatible with their education. Cordes and Dougherty (1993) state that people with high discrepancies between their expectations of professional development and real aspects of their job have higher Burnout levels. Individuals that are more vulnerable to the syndrome are commonly those that are strongly motivated and engaged with their jobs. To these individuals, working is part of the meaning of life and, if they do not find or lose meaning through the achievement of their goals and expectations, Burnout is a likely result (Van Dierendonck, Garssen, \& Visser, 2005). The high percentage is worrisome, considering that BS is a gradual process through which a person starts to lose meaning and his fascination about work, making room for feelings of frustration and lack of accomplishment (Maslach \& Leiter, 1997).

The variables that explain this dimension were constituted by the perception that the social environment of work, work content, work schedule and relationship with heads are stressors. A study with municipal public employees conducted by Malmann, Palazzo and Carlotto (2009) identified similar results, because feelings of poor accomplishment at work were associated with difficulties in the work environment.

The psychological exhaustion dimension reveals that nearly a third of the servants are performing their activities with feelings of emotional and physical fatigue, being superior to the prevalence of $26.1 \%$ $(\mathrm{n}=518)$ found in psychologists (Rodriguez \& Carlotto, 2014) and $17.8 \%(n=169)$ in professors (Costa et al., 2013). This dimension, generally related to work overload (Alarcon, 2011; Gil-Monte et al., 2016) can be explained by the nature of the activities of public servants, performed within a context of intensified work pace, high level of demands for productivity and fast processes (Carmo, 2014; Gomes, Guimaraes, \& Akutsu, 2017). According to Freudenberg (1974), it is common, about this syndrome, the existence of a strong sensation of frustration and exhaustion in relation to work, derived from the need to perform the latter quickly, due to excess of tasks.

This result can be understood as well as from stressors that explain this dimension, that is, it is possible to observe that the greater the perception that the developed work content, the social environment of work, work hours, physical conditions and relationship with heads are stressful, the greater the feeling of psychological exhaustion. Increased volume of actions subject to the Judiciary Power means increased demand for work, time servants stay in front of their computers and number of repetitive movements throughout a work day. However, these changes have not come along with adequate physical and structural conditions (Pai et al., 2014). A greater demand for work causes heads to pressure employees for greater performance, with delivery of activities on tight deadlines (Fogaça \& Coelho Junior, 2015).

The indolence dimension evidenced a prevalence of $17.3 \%$, figure superior to that found in professors $(5.9 \%, \mathrm{n}=169)$ (Costa et al., 2013) and higher to that of doctors $(9.9 \%, \mathrm{n}=631)$ (Tejada \& Gómez, 2012) and psychologists $(11.2 \%, \mathrm{n}=518)$ (Rodriguez \& 
Carlotto, 2014). This dimension is usually associated with the amount of assisted people and the need to deal with a specific public that comes with problematic situations, such as patients and students. In the case of public servants from the judiciary field, the new conception of management, aimed at the quality of life of society - therefore granting dignity to assisted people - relationships with users acquire new dynamics (Araújo, 2008). According to Silva and Barbosa (2016), indispensable individual competences to public servants are commitment, responsibility, ethics, knowing how to deal with people, empathy, warmness, goodwill and ability to handle information in an assertive manner. In this sense, the prevalence of indolence found in the present study reveals the impact of this change to workers. This understanding corroborates the results of a study carried out by Aquino (2010) with public servants from a Forum of Minas Gerais' Court of Law, in which workers referred that their images are associated with their usefulness and the benefits they can provide to users.

Indolence was explained by the perception of the social environment of work, public type, relationship with colleagues and heads as stressors, showing the importance interpersonal stressors related to work environment. It is worth highlighting that the relationship with clients has, in Burnout studies, a broad character (Cordes \& Douguerty, 1993), since not only the user of the service is considered but interactions with colleagues and heads are also taken into account. A study conducted by Gil-Monte et al. (2016) with public servants from the Spanish judiciary identified as a psychosocial stressor the relationship established internally with colleagues and heads and, externally, with the public served.

The prevalence of the guilt dimension reached $9.7 \%$, indicating the occurrence of feelings that the professional is violating some sort of ethics code or a norm derived from the prescription of his professional role. The assessment of this dimension is especially important because its presence is condition to a more damaging level of BS. The obtained percentage is quite inferior to that found in a study carried out with teachers (Gil-Monte, Carlotto, \& Câmara, 2011), which found $16.1 \%$. Thus, it is possible to ponder that most professionals understand they are developing their activities in accordance with the social expectations of their role, not representing a professional conflict. This result may be related to the less emotional involvement with clients, if compared to traditionally assistance-oriented professions such as teachers and healthcare workers. It is worth stressing as well the judiciary servant's work model, which is more standardized and formally defined (Mota \& Pereira, 2004).

In terms of guilt-predictor variables, the stressors are relationship with colleagues and type of public served. Results indicate that in these relations servants perceive they are not meeting the social expectations of their role. This discrepancy, generated by beliefs on how they should be performing their job in terms of relations established with others generates critical and unfavorable self-evaluations. Thus, the level of discrepancy is directly proportional to the level of guilt, which may cause dissatisfaction and frustration with work (Hochwarter, Perrewe, Meurs, \& Kacmar, 2007).

The study points to a picture that requires attention, bearing in mind the identification of 58 potential cases of Burnout Syndrome in professionally active people, mainly considering 2009 data by Dataprev indicating that Mental and Behavioral Disorders come third when it comes to the amount of sick pays among benefits granted by the Ministry of Social Security (2012). According to Jardim (2011), half of these sick pays are due to mood disorders, with $80 \%$ of the latter being for depression (F32-F34), which puts Brazil within the same trend observed in other countries, in which depression emerges as a major cause of work leaves.

This matter is worth attention due to the close relationship between depressive symptoms and Burnout. Since the beginning of studies about Burnout several authors (Bakker, Schaufeli, Demerouti, Janssen, Van Der Hulst, \& Brouwer, 2000; Maslach \& Jackson, 1981; Toker, Shirom, Shapira, Berliner, \& Melamed, 2005) have been warning about the need to carry out an adequate and differentiated diagnosis in relation to depression, bearing in mind that some symptoms of both aggravations are similar. Maslach and Jackson (1981) alert that, though related constructs, they are not synonymous.

The Brazil cost dimension of work leaves indicates the urgent need for public policies focused on preventing and protecting against risks associated with labor activities so this scenario actually changes (Ministry of Social Security, 2012). In the specific case of Burnout Syndrome, the scenario in which it develops is the organizational one and, therefore, changes in the work organization should be sought, aiming at minimizing present occupational stressors.

The study shows as strengths its possibility of generalization to its target population and the use of 
mediation instrument with adequate psychometric properties. As for limitations, one of them is the use of measures deriving from self-reports, which may lead to biases related to social desirability, and the other is the "health worker effect", a peculiar matter in cross-sectional studies about occupational epidemiology, which oftentimes excludes an eventual ill one (McMichel, 1976). This is a situation that can underestimate the size of identified risks, as the most affected ones, probably Profile 2 servants, cannot keep up with their jobs, being away from work due to leaves for health treatments.

Certainly, further studies must be conducted so as to enable comparisons with other public institutions of similar and different functionalities and in different Brazilian states. Thus, by expanding knowledge about Burnout among public servants, category still little addressed in national studies, it is possible to subsidize actions towards the prevention and rehabilitation of this type of occupational disease.

\section{References}

Agranonik, M., \& Hirakata, V. N. (2011). Cálculo de tamanhode amostra:Proporções. RevistaHCPA,31(3), 382-388. Recuperado de http://www.lume.ufrgs. br/bitstream/handle/10183/159229/001015562. pdf?sequence $=1$

Alarcon, G. M. (2011). A meta-analysis of burnout with job demands, resources, and attitudes. Journal of Vocational Behavior, 79(2), 549-562. doi: 10.1016/j. jvb.2011.03.007

Aquino, J. M. C. de. (2010). Identificação e imagem do servidor público: Um estudo com os usuários do Tribunal de Justiça do Estado de Minas Gerais. Dissertação de Mestrado, Universidade FUMEC, Belo Horizonte, Brasil. Recuperado de http://www.face.fumec.br/ anexos/cursos/mestrado/dissertacoes/completa/ jussara_canuto.pdf

Araújo, S. M. L. de. (2008). Taxas e tarifas no serviço público. Dissertação de Mestrado, Universidade Federal do Paraná, Curitiba, Brasil. Recuperado de https://acervodigital.ufpr.br/bitstream/ handle $/ 1884 / 15152 /$ Taxas? sequence $=2$

Bakker, A. B., Schaufeli, W. B., Demerouti, E., Janssen, P. P., Van Der Hulst, R., \& Brouwer, J. (2000). Using equity theory to examine the difference between burnout and depression, 13(3), 247-268. doi: 10.1080/10615800008549265
Balassiano, M., Tavares, E. E., \& Pimenta, R. da C. (2011). Estresse ocupacional na administração pública brasileira: Quais os fatores impactantes? Revista de Administração Pública, 45(3), 751-774. doi: 10.1590/S0034-76122011000300009

Batista, J. B. V., Carlotto, M. S., Coutinho, A. S., \& Augusto, L. G. S. (2011). Síndrome de Burnout: Confronto entre o conhecimento médico e a realidade das fichas médicas. Psicologia em Estudo, 16(3), 429-435. doi: 10.1590/S1413-73722011000300010

Carlotto, M. S. (2010). Síndrome de Burnout: diferenças segundo níveis de ensino. Psico, 41(4), 495-502. Recuperado de https://dialnet.unirioja.es/servlet/ articulo?codigo $=5161401$

Carlotto, M. S., \& Câmara, S. G. (2008). Análise da produção científica sobre a Síndrome de Burnout no Brasil. Psico, 39(2), 152-158. Recuperado de https://dialnet.unirioja.es/servlet/ articulo?codigo $=5161619$

Carlotto, M. S., Gil-Monte, P. R., \& Figueiredo-Ferraz, H. (2015). Factor analysis of the Spanish Burnout Inventory among public administration employees. Japanese Psychological Research, 57(2), 155-165. doi: 10.1111/jpr.12071

Carmo, M. M. do. (2014). "Tribunal da cidadania?! Pra quem?!": Qualidade de vida no trabalho em um órgão do Poder Judiciário brasileiro. Dissertação de Mestrado, Universidade de Brasília, Brasil. Recuperado de http://www.repositorio.unb.br/ bitstream/10482/17111/1/2014_MarinaMaiaDoCarmo.pdf

Cavalcante, P. (2017). Gestão pública contemporânea: do movimento gerencialista ao pós - NPM. Instituto de Pesquisa Econômica Aplicada. Brasília: Rio de Janeiro: IPEA. Recuperado de http://repositorio.ipea.gov.br/bitstream/11058/8027/1/ td_2319.pdf >

Chopra, P. (2009). Mental health and the workplace: issues for developing countries. International Journal of Mental Health Systems, 3(4), 1-9. doi: 10.1186/1752-4458-3-4

Cordes, C. L., \& Dougherty, T. W. (1993). A review and integration of research on job burnout. Academy of Management Review, 18(4), 632-636. doi: $10.2307 / 258593$

Costa, L. S. T., Gil-Monte, P. R., Possobon, R. F., \& Ambrosano, G. M. B. (2013). Prevalência da Síndrome 
de Burnout em uma amostra de professores universitários brasileiros. Psicologia: Reflexão e Crítica, 26(4), 636-642. doi: 10.1590/S0102-79722013000400003

Coutinho, M. J. V. (2000). Administração pública voltada para o cidadão: Quadro teórico-conceitual. Revista do Serviço Público, 51(3), 40-73. doi: 10.21874/rsp. v51i3.331

Falavigna, A., \& Carlotto, M. S. (2013). Tendência Temporal de Afastamento do Trabalho por Transtornos Mentais e Comportamentais em Enfermeiros (1998-2008). Revista Psicologia: Organizacõos e Trabalho, 13(3), 363-372. Recuperado de http://pepsic. bvsalud.org/pdf/rpot/v13n3/v13n3a12.pdf

Field, A. (2009). Descobrindo a estatística usando o SPSS. $2^{\mathrm{a}}$ ed. Porto Alegre: Artmed.

Fogaça, N., \& Coelho Junior, F. A. (2015). A hipótese "trabalhador feliz, produtivo": O que pensam os servidores públicos federais. Cadernos EBAPE.BR, 13(4), 759-775. doi: 10.1590/1679-395126953

Fonseca, R., \& Carlotto, M. S. (2011). Saúde mental e afastamento do trabalho em servidores do Judiciário do Estado do Rio Grande do Sul. Psicologia em Pesquisa, 5(2), 117-125. Recuperado de http:// pepsic.bvsalud.org/scielo.php?script=sci_arttext\& pid=S1982-12472011000200004

Freudenberger, H. J. (1974). Staff burnout. Journal of Social Issues, 30(1), 159-165. doi: 10.1111/j.15404560.1974.tb00706.x

Gil-Monte, P. R. (2005). El sindrome de quemarse por el trabajo (burnout). Una enfermedad laboral en la sociedad del bienestar. Madrid: Pirámide.

Gil-Monte, P. R. (2008). El síndrome de quemarse por el trabajo (burnout) como fenómeno transcultural. Información Psicológica, (91-92), 4-11. Recuperado de https://www.uv.es/unipsico/pdf/Publicaciones/ Articulos/01_SQT/2007_08_Gil_Monte.pdf

Gil-Monte, P. R. (2011). CESQT. Cuestionario para la Evaluación Del Sindrome de Quemarse por el Trabajo. Madrid, Spain: TEA.

Gil-Monte, P. R. (2012). The influence of guilt on the relationship between burnout and depression. European Psychologist, 17(3), 231-236. doi: 10.1027/1016-9040/a000096

Gil-Monte, P. R. (2014). Los riesgos psicosociales en el trabajo: estrés, mobbing, burnout, depresión In:
R. L. Martín (Org.), Educación y entorno territorial de la Universitat de València. Conferencias impartidas en el Programa Universitat $i$ Territori (pp. 259-265). València: Universitat de València.

Gil-Monte, P. R., Carlotto, M. S., \& Câmara, S. G. (2010). Validation of the Brazilian version of the "Spanish Burnout Inventory" in teachers. Revista de Saúde Pública, 44(1), 140-147. doi: 10.1590/ S0034-89102010000100015

Gil-Monte, P. R., Carlotto, M. S., \& Câmara, S. G. (2011). Prevalence of burnout in a sample of Brazilian teachers. The European Journal of Psychiatry, 25(4), 205-212. doi: 10.4321/s0213-61632011000400003

Gil-Monte, P. R., López-Vílchez, J., Llorca-Rubio, J. L., \& Sánchez Piernas, J. (2016). Prevalencia de riesgos psicosociales en personal de la administración de justicia de la Comunidad Valenciana (España). Liberabit, 22(1), 7-19. doi: 10.24265/liberabit.2016. v22n1.01

Gomes, A. O., Guimaraes, T. A., \& Akutsu, L. (2017). Court caseload management: the role of judges and administrative assistants. Revista de Administração Contemporânea, 21(5), 648-665. doi:10.1590/1982-7849rac2017160179

Harrison, B. J. (1999). Are you destined to burn out? Fund Raising Management, 30(3), 25-27.

Hochwarter, W. A., Perrewe, P. L., Meurs, J. A., \& Kacmar, C. (2007). The interactive effects of work-induced guilt and ability to manage resources on job and life satisfaction. Journal of Occupational Health Psychology, 12(2), 125-135. doi: 10.1037/1076-8998.12.2.125

Jain, A., Saeed, K., Arnaout, S., \& Kortum, E. (2012). The psychosocial environment at work: An assessment of the World Health Organization Regional Office for the Eastern Mediterranean. Eastern Mediterranean Health Journal, 18(4), 325-331. doi: 10.26719/2012.18.4.325

Jardim, S. (2011). Depressão e trabalho: Ruptura de laço social. Revista Brasileira de Saúde Ocupacional, 36(123), 84-92. doi: 10.1590/S0303-76572011000100008

Laranjeira, C. A. (2009). O contexto organizacional e a experiência de estress: Uma perspectiva integrativa. Revista de Salud Pública, 11(1), 123-133. doi: 10.1590/S0124-00642009000100013 
Lima, J. O., \& Silva, A. B. (2015). Determinantes do desenvolvimento de competências coletivas na gestão de pessoas. Revista de Administração Mackenzie, 16(5), 41-67. doi: 10.1590/1678-69712015/ administracao.v16n5p41-67

Louro, A. C., W. R. Santos, \& Zanquetto Filho, H. (2017). Productivity antecedents of Brazilian Courts of Justice: Evidence from Justiça em Números, Brazilian Administration Review, 14(4), e170032. doi. org/10.1590/1807-7692bar2017170032

Malmann, C., Palazzo, L., \& Carlotto, M. S. (2009). Fatores associados à Síndrome de Burnout em funcionários públicos municipais. Psicologia: Teoria e Prática, 11(2), 69-82. Recuperado de http://pepsic. bvsalud.org/pdf/ptp/v11n2/v11n2a06.pdf

Maslach, C., \& Jackson, S. E. (1981). The measurement of experienced burnout. Journal of Occupational Behavior, 2(2), 99-113. doi: 10.1002/ job.4030020205

Maslach, C., \& Leiter, M. P. (1997). The truth about burnout: How organization cause, personal stress and what to do about it. San Francisco: Jossey-Bass.

McMichael, A. J. (1976). Standardized mortality ratios and the healthy worker effect: Scratching beneath the surface. Journal of Оссираtional and Environmental Medicine, 18(3), 165-168. doi: 10.1097/00043764-197603000-00009

Ministério da Saúde. (2001). Doenças relacionadas ao trabalho: manual de procedimentos para os serviços de saúde. Brasília: Ministério da Saúde, OPAS/OMS.

Ministério da Previdência Social (2012). Saúde e segurança do trabalhador. Recuperado de http://www. mps.gov.br/conteudoDinamico.php?id=39

Mota, F. C. P., \& Pereira, L. C. B. G. (2004). Introdução à organização burocrática (2a edição). São Paulo: Pioneira Thomson Learning.

Nogueira, J. M. M., Oliveira, K. M. M. de, Vasconcelos, A. P. de, \& Oliveira, L. G. L. (2012). Estudo exploratório da eficiência dos Tribunais de Justiça estaduais brasileiros usando a Análise Envoltória de Dados (DEA). Revista de Administração Pública, 46(5), 1317-1340. doi: 10.1590/ s0034-76122012000500007

Oliveira, L. A., Baldaçara, L. R., \& Maia, M. Z. B. (2015). Afastamentos por transtornos mentais entre servidores públicos federais no Tocantins.
Revista Brasileira de Saúde Ocupacional, 40(132), 156169. doi: 10.1590/0303-7657000092614

Pai, D. D., Lautert, L., Tavares, J. P., Souza Filho, G. de A., Dornelles, R. A. N., \& Merlo, Á. R. C. (2014). Repercussões da aceleração dos ritmos de trabalho na saúde dos servidores de um juizado especial. Saúde e Sociedade, 23(3), 942-952. doi: 10.1590/ S0104-12902014000300017

Reis, A. T. L. (2016). Desafios da administração pública no contexto atual. Perspectivas em Politicas Públicas, IX(18), 255-260. Recuperado de http:// revista.uemg.br/index.php/revistappp/article/ viewFile/2051/1035

Rodriguez, S. Y. S., \& Carlotto, M. S. (2014). Prevalência e fatores associados à síndrome de burnout em psicólogos. Ciencia \& Trabajo, 16(51), 170-176. doi: $10.4067 / \mathrm{s} 0718-24492014000300008$

Secchi, L. (2009). Modelos organizacionais e reformas da administração pública. Revista de Administração Pública, 43(2), 347-369. doi: 10.1590/ s0034-76122009000200004

Silva, F. K. L., \& Barbosa, M. A. C. (2016). O perfil de competências individuais do Servidor Público do Judiciário na Região do Vale do São Francisco. Id on Line Revista Multidisciplinar e de Psicologia, 10(30), 115-129. doi: 10.14295/idonline.v10i30.468

Suárez, D. F., \& Esparza, N. (2015).Institutional change and management of public-nonprofit partnerships. American Review of Public Administration, 8, 1-18. doi: 10.1177/0275074015619482

Tejada, P., \& Gómez V. (2012). Prevalencia y factores demográficos y laboral associados al burnout de psiquiatras em Colombia. Universitas Psychologica, 11(3), 863-873. Disponível em: < http://www.redalyc.org/pdf/647/64724634015.pdf >

Toker, S., Shirom, A., Shapira, I., Berliner, S., \& Melamed, S. (2005). The association between burnout, depression, anxiety, and inflammation biomarkers: C-reactive protein and fibrinogen in men and women. Journal of occupational health psychology, 10(4), 344-362. doi: 10.1037/1076-8998.10.4.344

World Health Organization (2017). Protecting workers' health. Accessed in http://www. who.int/news-room/fact-sheets/detail/ protecting-workers $\% 27$-health 
Van Dierendonck, D., Garssen, B., \& Visser, A. (2005).

Recebido em: 23/01/2018 Burnout prevention through personal growth. International Journal of Stress Management, 12(1), 62-77. Reformulado em: 28/09/2018 doi: 10.1037/1072-5245.12.1.62

Aprovado em: 03/10/2018

Sobre as autoras:

Mary Sandra Carlotto is a psychologist, holds a PhD in Social Psychology from the University of Santiago de Compostela (USC / Spain) and is a professor of the Postgraduate Program in Psychology at Universidade do Vale do Rio dos Sinos (UNISINOS), Rio Grande do Sul/Brazil. Her research interests include Occupational Health Psychology (stress at work, burnout syndrome, work-related mental disorders, technostress and bullying).

ORCID: http://orcid.org/0000-0003-2336-5224

E-mail:mscarlotto@pesquisador.cnpq.br

Sheila Gonçalves Câmara is a psychologist; holds a $\mathrm{PhD}$ in Psychology from the Pontifical Catholic University of Rio Grande do Sul (PUCRS/Brazil). Professor of the Department of Psychology and the Graduate Program in Psychology and Health of the Universidade Federal de Ciências da Saúde de Porto Alegre (UFCSPA, Brazil). Researches in the areas of public health, worker health, and adolescent health.

ORCID: http://orcid.org/ ORCID: 0000-0001-6761-7644.

E-mail: sheilac@ufcspa.edu.br

Contato com as autoras:

Profa. Dra. Mary Sandra Carlotto

Universidade do Vale do Rio dos Sinos - Programa de Pós-Graduação em Psicologia

Sala E01-118

Av. Unisinos, 950 - Cristo Rei

São Leopoldo-RS, Brasil

CEP: 93022-750 